\title{
MTA Cement
}

National Cancer Institute

\section{Source}

National Cancer Institute. MTA Cement. NCI Thesaurus. Code C66857.

A cement like material used for apical seals and as a reparative material for perforation of the tooth root. 